\title{
Compositional and physicochemical changes in waste materials and biogas production across 7 landfill sites in $\mathrm{UK}$
}

Frank, R. R. ${ }^{1,2}$, Cipullo, S. ${ }^{1}$, Garcia J. ${ }^{1}$, Davies, S. ${ }^{3}$, Wagland, S.T. ${ }^{1}$, Villa, R. ${ }^{1}$, Trois, C. ${ }^{2}$, Coulon, F. ${ }^{1,2 *}$

${ }^{1}$ School of Water, Energy and Environment, Cranfield University, MK43 0AL, UK

${ }^{2}$ Centre for Research in Environmental, Coastal and Hydrological Engineering (CRECHE), School of Engineering, University of KwaZulu-Natal, Howard College Campus, Durban, 4041, South Africa.

${ }^{3}$ Viridor Waste management Ltd, Viridor House, Priory Bridge Road, Taunton, Somerset, TA1 1AP.

Corresponding author: f.coulon@ cranfield.ac.uk ; Tel: +44 (0)1234 754981

\begin{abstract}
The aim of this study was to evaluate the spatial distribution of the paper and fines across seven landfill sites (LFS) and assess the relationship between waste physicochemical properties and biogas production. Physicochemical analysis of the waste samples demonstrated that there were no clear trends in the spatial distribution of total solids (TS), moisture content (MC) and waste organic strength (VS) across all LFS. There was however noticeable difference between samples from the same landfill site. The effect of landfill age on waste physicochemical properties showed no clear relationship, thus, providing evidence that waste remains dormant and nondegraded for long periods of time. Landfill age was however directly correlated with
\end{abstract}


the biochemical methane potential (BMP) of waste; with the highest BMP obtained from the most recent LFS. BMP was also correlated with depth as the average methane production decreased linearly with increasing depth. There was also a high degree of correlation between the Enzymatic Hydrolysis Test (EHT) and BMP test results, which motivates its potential use as an alternative to the BMP test method. Further to this, there were also positive correlations between MC and VS, VS and biogas volume and biogas volume and $\mathrm{CH}_{4}$ content. Outcomes of this work can be used to inform waste degradation and methane enhancement strategies for improving recovery of methane from landfills.

Keywords: Waste composition; Waste physicochemistry; Biochemical methane potential; Waste-biogas relationships; Enzymatic hydrolysis test. 


\section{Introduction}

MSW in landfills is composed of a number of different organic and inorganic materials, such as food, paper, wood, plastics, glass, metal and inert materials (Machado et al., 2009). The composition of this waste within any landfill site is highly variable, and is affected by a number of factors, including: location, climate, landfill age and local policy drivers.

Bacterial decomposition of the waste accounts for the majority of the landfill gas produced which principally consists of methane and carbon dioxide ranging between $50-55 \%$ and $40-45 \%$, respectively (Johari et al., 2012; Donovan et al., 2011). The process makes use of a complex, interactive network of aerobic and anaerobic microorganisms to degrade organic material (food, garden waste, wood, paper) (Godley et al., 2004). A number of chemical reactions can also account for landfill gas production on account of the combination of waste materials during disposal (Bogner and Spokas, 1993). The quantity of landfill gas along with its methane content is influenced by several factors, which include among others the types and age of the waste buried in the landfill, the quantity and types of organic compounds in the waste, and the moisture content and temperature of the waste (Emkes et al., 2015). Methane is highly combustible, and as a result can be exploited as a source of renewable energy (Rada et al., 2015). In the UK, the utilisation of landfill gas for energy has been particularly successful (Brown and Maunder, 1994; Emkes et al., 2015). The UK however have adopted a number of waste management policies aimed at reducing the amount of waste, in particular biodegradable waste, sent to landfill sites (Laner et al., 2012). The EU Landfill Directive 99/31/EC (1999) further transformed trends in MSW disposal by creating ambitious targets to shift waste 
away from landfill sites. This was coupled with requirements for landfill sites to install best-practise methane recovery technologies (Defra, 2006). Other policy drivers in the UK that incentivise waste diversion from landfill include: the introduction of landfill tax (1996), the Landfill Allowance Trading Schemes (LATS) (2005/06) (Defra, 2006), the EU Waste Framework Directive 2008/98/EC (European Commission, 2008) and the Renewable Energy Directive 2009/28/EC (European Commission, 2009). UK waste policy drivers have certainly led to a significant change in the composition of waste currently in UK landfill sites, and consequently on gas production. The effect on the future landfill gas generation is still to be fully elucidated.

A number of aerobic and anaerobic methods are currently available to assess the biodegradability of waste thus providing insight into the potential biogas production. Aerobic tests such as DR4 and ASTM, are typically more rapid than anaerobic tests but do not fully measure biodegradability (Wagland et al., 2008). On the contrary, anaerobic tests (i.e. GB21, GS90 and BM100) provide a more complete assessment of waste biodegradability but the tests take substantially longer (> 30 days) and therefore are not suitable for routine monitoring application (Wagland et al., 2009; Shanmugam and Horan, 2008). Therefore, the development of a rapid, low cost test method, which can accurately assess the biodegradability of waste, will be valuable for monitoring and predictive application.

Previously an enzymatic hydrolysis tests (EHT) method was developed by Wagland et al. (2007, 2008), which followed work by Godley et al (2004) on enzymatic hydrolysis of cellulosic material and Rodriguez et al (2001) on the enzymatic availability of cellulose in organic waste. Studies published to date on using the EHT 
indicate a good correlation between EHT results and the standardised BM 100 test results (Wagland et al., 2008 and 2011).

The aim of this study was to determine the current state of waste at UK landfill sites, i.e. compositional and physicochemical properties, and its relationship with landfill gas production. The specific objectives were to (1) evaluate the spatial distribution of unspent carbon at seven landfill sites, (2) determine the physicochemical properties of waste distributed between different landfill sites and a range of depths, (3) understand the relationship between organic waste distribution, waste composition and waste physicochemistry, and its effect on landfill gas production and methane yield and (4) evaluate the use of enzymatic hydrolysis as a feasible, cost-effective and rapid test method to determine potential biogas production.

\section{Materials and Methods}

\subsection{Waste origin}

95 municipal solid waste (MSW) samples were obtained from 7 UK landfill sites (LFS) during drilling activities between October 2013 and June 2014. The sites are referred to as LFS 1-7. Two separate tests sites were evaluated at LFS 4, which are referred to as LFS 4.1 and LFS 4.2, respectively. Background information on the LFS is provided in Table 1. Approximately $5 \mathrm{~kg}$ of waste was sampled at each depth. The waste samples were then collected within a maximum of 2 weeks after drilling and stored at $4{ }^{\circ} \mathrm{C}$ until analysis. 


\subsection{Waste samples preparation and characterisation}

Waste was screened and separated by hand into plastics, paper and fines as defined by Quaghebeur et al. (2013) (degraded garden and food materials), textiles, glass and metal. Waste composition was reported as a percentage contribution of total weight. Dry matter (DM) or Total solids (TS) and Volatile Solids (VS) of the paper and fines were determined in triplicate following the procedure BS EN 12879:2000 (Wagland 2008). This was done to calculate the amount of moisture and VS present in the waste samples. It should be noted though that the VS determination should not be taken as a direct correlation with the organic part of the waste as the loss of volatile organic substances (i.e. plastics) can occur and therefore giving high VS results (Section 5 of the BS EN 12879:2000 standards). The waste samples were dried at $105{ }^{\circ} \mathrm{C}$ for $24 \mathrm{~h}$ for the DM determination and at $505{ }^{\circ} \mathrm{C}$ for $4 \mathrm{~h}$ for the VS determination. The paper and fines samples were shredded to particle size of $8 \mathrm{~mm}$ as recommended by Wagland (2008). $\mathrm{pH}$ and soluble Chemical Oxygen Demand (sCOD) of the separated paper and fines were determined according to the Standard Analytical Methods published by the American Public Health Association (APHA, 1995). sCOD was conducted in duplicate due to reliability of test kits while all other tests were conducted in triplicate.

\subsection{Biochemical methane potential}

The BMP test were carried out as described in Garcia et al. (2016). Briefly each BMP test was conducted by mixing $20 \mathrm{~g}$ loss on ignition (LOI) equivalent of the paper and fines with $40 \mathrm{~g}$ LOI equivalent of digested primary sludge in a $1 \mathrm{~L}$ bottle. Sludge was obtained from the Cotton Valley wastewater treatment plant in Milton 
Keynes, UK and was used to introduce the active microbial community. The bottles were filled with distilled water up to $500 \mathrm{ml}$, leaving a headspace of $500 \mathrm{ml}$, and flushed with nitrogen gas to set anaerobic conditions. Bottles were thereafter sealed, and incubated at $38^{\circ} \mathrm{C}$ in a water bath. The volume of biogas was measured volumetrically daily until no more biogas was produced. The concentration of methane in the biogas was determined once a week using either gas chromatography or a gas analyser (Servomex $1440 \mathrm{GA}$ ), depending on the availability of the measuring device. Further to this, sludge alone and sludge + cellulose (both in the absence of waste) were used as control BMP tests as recommended in the WRAP guidelines (Walker et al., 2010). Cellulose was used at a concentration of $10 \mathrm{~g} \mathrm{~kg}^{-1}$. The amount of biogas produced was calculated considering the area of the columns (specific to this study) and the environmental conditions of the laboratory, according to Equation 1 (Walker et al., 2010):

$$
V_{s t p}=\frac{T_{s t p} \cdot A}{T_{a t m} \cdot P_{s t p}} \cdot\left[\left(P_{a t m-} P_{H 20}-p \cdot g \cdot(H-h)\right) \cdot h\right]
$$

[Equation 1]

where, $\mathrm{V}_{s t p}=$ volume of biogas (in standard conditions), $\mathrm{T}_{s t p}=$ standard temperature, $\mathrm{T}_{a t m}=$ ambient temperature, $\mathrm{P}_{s t p}=$ standard pressure, $\mathrm{P}_{a t m}=$ ambient pressure, $\mathrm{P}_{H 2 O}=$ pressure of the water, $\rho=$ density, $\mathrm{g}=$ gravity, $\mathrm{H}=$ distance from the bottom to the top of the column, $\mathrm{h}=$ void distance in the column.

The biogas production of the inoculum was subtracted when calculating the amount of the biogas produced by the waste samples. The volume of biogas produced is 
presented as L biogas per $\mathrm{Kg}$ total wet waste. Methane production is presented in $\mathrm{ml}$ $\mathrm{CH}_{4} / \mathrm{g}$ VS waste.

\subsection{Enzymatic Hydrolysis tests}

Enzymatic Hydrolysis tests (EHT) were carried out as previously described by Wagland et al., (2008). Briefly, an equivalent waste sample of $3 \mathrm{~g}$ of LOI was placed in $250 \mathrm{ml}$ glass bottles. $150 \mathrm{ml}$ of $0.1 \mathrm{M}$ pH 5 buffer solution was then added to each bottle. Approximately $20 \mathrm{ml}$ of sample was removed and filtered using $0.45 \mu \mathrm{m}$ filters to remove the solids present in the liquid. The filtrate was then analysed for soluble chemical oxygen demand (sCOD). The value obtained was recorded as Phase 1 oxygen demand. Then the sample mixture of the bottles was autoclaved at $121^{\circ} \mathrm{C}$ for 15 minutes to remove any biological activity and thus to ensure that SCOD release after enzyme addition was due to enzyme hydrolysis. Again, $20 \mathrm{ml}$ of sample was removed and filtered for SCOD analysis. The value obtained is the Phase 2 oxygen demand. Finally, between $10-20 \mathrm{ml}$ of prepared enzyme solution (800 $\mathrm{U} / \mathrm{mg}$ cellulose:200 U/mg hemicellulose) was added to the sample mixture as described in Table 2. These concentrations were used at they showed optimal results during preliminary tests (data not shown). All the bottles were placed in an orbital shaker and incubated at $50^{\circ} \mathrm{C} .20 \mathrm{ml}$ of sample were removed and filtered after 20 hours of incubation for the Phase 3 sCOD analysis. EHT results were obtained by calculating the change in COD between phases 2 and 3 according to Equation 2 .

$$
s C O D(g / g V S)=\frac{s C O D(m g / L)}{V S \text { Concentration }(g / l) * 1000}
$$


Results from EHT are expressed in g sCOD / $\mathrm{g}$ VS and converted to L per gram sample for comparison with results from BMP tests. EHT was conducted in duplicate on 3 representative MSW samples from LFS 1 (core 1- 4 m, 6 m, 10 m), 3 from LFS 2 (core 2-10 m, $20 \mathrm{~m}, 30 \mathrm{~m}$ ) 4 from LFS 3 (core 1 and core 5- $10 \mathrm{~m}, 20 \mathrm{~m}$ ) and 3 from LFS 4.1 ( $3 \mathrm{~m}, 9 \mathrm{~m} 15 \mathrm{~m}$ ). Samples were chosen to give a representative sample of each landfill site at different depths while maintaining the core.

\subsection{Statistical analysis}

Statistical analysis was carried out using SPSS version 22. One-way analysis of variance (ANOVA) tests were conducted to determine differences in waste composition and physicochemical properties between independent variables; landfill sites and depth. Depth was categorised into 3 groups: 0-9 m, 10-19 m, and 20+ m. Two-way analysis of variance tests was also evaluated for the independent variables. It was determined that there was no significant interaction effect for any of the independent variable. All tests satisfied assumptions of normality (KolmogorovSmirnov test) and homogeneity of variance (Levene's test). Significance level was set at 0.05 . The relationships between waste depth, TS, VS, sCOD, organic composition, biogas volume and methane content were assessed using a Draftsman's plot of the Primer statistical package version 6. 


\section{Results and Discussion}

\subsection{Waste composition}

The spatial distribution of the paper and fines across the seven landfill sites is shown in Figure 1. A statistical difference was observed in the distribution of paper and fines across the seven landfill sites $[F(7,83)=8.486, \mathrm{p}<0.01]$. This was expected as the sites differed in their age, waste types, capacity and region. There was also a statistical difference in the amount of fine material distributed between waste layers $(0-9 \mathrm{~m}, 10-19 \mathrm{~m}$ and $20+\mathrm{m})[\mathrm{F}(2,88)=5.111, \mathrm{p}<0.01]$. This finding is in agreement with previous studies on the characterisation of excavated waste samples who found the composition of organic fine materials to increase with depth (Mor et al, 2006; Qaughebeur et al (2013); Garcia et al., 2016).

Overall, results showed that there is a large amount of unspent organic material (between 20 and $90 \%$ ) distributed variably in the surface waste layers (above $20 \mathrm{~m}$ ) throughout all the test sites (Figure 2). Moreover, higher proportions were observed below $20 \mathrm{~m}$ (Figure 1). This is likely on account of waste in lower layers being entombed and therefore unable to undergo waste stabilisation, as suggested by Reinhart et al (2002). The variability in its distribution also implies that there are no site-specific physical, chemical or biological factors which influence its degradation, particularly at surface depths.

\subsection{Physicochemical properties of waste}

A summary of the physicochemical properties (TS, VS, sCOD, pH and MC) of the paper and fines from all LFS samples according to depth is presented in Table 3. Total solids $(\mathrm{TS})[\mathrm{F}(2,88)=0.235, \mathrm{p}=0.791]$ and $\mathrm{VS}[\mathrm{F}(2.88)=2.429, \mathrm{p}=0.094]$ 
showed no statistical difference between the waste layers across all landfill sites. This indicated that overall, there were no defined trends in the spatial distribution of paper and fines across all landfill sites tested. Mor et al (2006) suggests that leachate accumulates at the bottom of the waste cell, causing the waste near the bottom to become saturated. In situ landfill waste data attained in this study does not correspond. There was however a statistical difference in $\operatorname{TS}[\mathrm{F}(7.83)=3.814, \mathrm{p}<$ 0.01) between landfill sites, which is understandable due to variations in climate, landfill geomorphology and waste composition between the landfill sites. There was also a significant difference in $\operatorname{VS}[\mathrm{F}(7.83)=3.948, \mathrm{p}<0.01]$ between landfills, which is likely due to variations in landfill age (Table 1; Figure 2). Further to this, there was no particular trend observed between paper and fines, TS, VS and landfill age, which suggested that the age of landfill did not directly influence the organic strength of the waste (Figure 2). One possible hypothesis for this is presented by Reinhart et al (2002), who propose that conventional sanitary landfills are designed and engineered to prevent moisture from entering the waste mass and in doing so, prevents waste from degrading for long periods of time. This study provides empirical field evidence of genuine landfill waste samples analysis that current landfill practises allow waste to remain dormant for long periods of time, and therefore, regardless of landfill age, contains a high content of paper and fines with high organic strength (Table 3; Figure 2).

The average $\mathrm{pH}$ across all landfill sites was between 7 and 8 (data not shown), indicating that sites were either in, or in a transition towards a methanogenic state (Adhikari et al., 2014; Lee et al., 2010). The strong influence of $\mathrm{pH}$ on the anaerobic waste degradation process is demonstrated by Staley et al (2011). The authors 
suggest $\mathrm{pH}$ is a primary driver facilitating microbial activity during different stages of anaerobic waste degradation. In this study the results showed no observable trend between $\mathrm{pH}$ and landfill depth thus suggesting that the different stages of waste degradation (acidogenesis, acetogenisis and methanogenesis) were not defined by landfill depth (a variation of which is the relative age of waste within a landfill). This therefore suggests that waste degradation processes occur in micro-niches across different depths within the waste cell, as described by Staley et al (2011).

\subsection{Biochemical methane potential test (BMP)}

BMP tests were conducted on each paper and fines samples to determine the maximum amount of biogas and methane content which could be attained per mass of waste under optimal conditions (Figures 3 and 4). There was a significant difference in the average amount of biogas produced from the paper and fines across the seven tested landfill sites, (Figure 3; $F(7,83)=6.095, \mathrm{p}<0.01$ ). Waste from LFS 5 and 7 produced approximately 4 and 2 times higher amounts of biogas than the other sites, respectively. The same trend occurred in methane yield as LFS 5 and 7 produced significantly higher amounts of $\mathrm{CH}_{4}$ per gram VS MSW (Figure 4). These two landfill sites are the youngest LFS, being 8 and 7 years old respectively. The relationship between landfill age and biochemical methane yield is shown in Figure

5. These results are supported by Bogner and Spokas (1993), who proposed that landfill age is a primary factor influencing landfill methane balance; along with engineering and management practises and water balance. Full-scale in situ evidence confirming this relationship is rare (Bogner and Spokas, 1993). 
Results also demonstrated a statistical difference in the BMP of the paper and fines according to landfill depth $[\mathrm{F}(2,88)=5.213, \mathrm{p}<0.01]$. The average methane production decreased linearly with increasing depth being 86,35 and $25 \mathrm{ml} \mathrm{g}^{-1} \mathrm{VS}^{-1}$, for depths of 0-9 m, 10-19 m and 20+ m, respectively (Figure 6). Little work has been done to spatially map methane potential of waste within landfill sites. Understanding how waste with high methane potential is spatially distributed can be used to inform strategies for improving recovery of methane from landfills. Based on these observations, it is likely that methane enhancement strategies that focus on the surface layers of younger landfills would yield more significant results.

\subsection{Relationships between waste physicochemical properties and biogas production}

The relationship between the spatial distribution of the paper /fines fraction and the physicochemistry and biogas/Biochemical methane production is shown in Figure 6. There was a positive relationship between MC and VS, i.e. volatile solids content was higher in wetter waste. It was also expected that there would be a relationship between VS and SCOD, as a positive correlation was suggested by Contreras et al (2002). Results from our study did not support this finding. MC percentage was negatively correlated to TS \% which was expected. There was also a weak negative correlation between the paper and fines percentage and biogas production. Results also indicated a positive relationship between $\mathrm{MC}$ and $\mathrm{CH}_{4}$ production, $\mathrm{VS}$ and biogas volume, and biogas volume and $\mathrm{CH}_{4}$ content.

The relationship between biogas production and $\mathrm{CH}_{4}$ content indicated that sites which typically produce high levels of biogas also produce high amounts of $\mathrm{CH}_{4}$. As 
a result, the amount of biogas produced by a landfill site could also be indicative of the total potential amount of methane, and thus potential energy production.

$\mathrm{CH}_{4}$ levels did not show any other trend with organic content or SCOD but did show a weak positive relationship with VS, similar to that of biogas volume. The fact that the waste organic composition did not correlate with biogas production suggests that the quantity (composition) of organic material cannot be used as an indication of potential biogas production. The organic strength however, as represented by the VS content, provides a better indication of biogas potential. Shanmugam and Horan (2008) confirmed the importance of VS in biogas production. Since VS and sCOD are both measures of organic strength, the lacking correlation between waste sCOD and biogas production further supports the relationship between VS and biogas production.

\subsection{EHT-BMP correlation}

EHT were conducted on each waste sample in duplicate across the 7 landfill sites. Comparison of the average EHT and BMP results across the 7 landfill sites indicated a strong correlation between the two tests (Figure 7). This finding supports current indications that EHT can be successfully used as a more rapid alternative test to determine biogas production when compared to BMP tests (Wagland et al., 2008, 2009; Garcia et al., 2016). While the well-established BMP tests are considered robust and accurate, they often require a relatively long time for completion which limits their practicality and applicability for waste managers (Wagland et al., 2008). EHT test method maintains result accuracy while reducing the time required for results. The use of EHT for biogas potential is still in its infancy; however there is a 
growing amount of evidence which suggests that it can be successfully used for biogas prediction (Wagland et al., 2007, 2008, 2009, 2011; Godley et al., 2004). A limitation of the EHT method compared to BMP tests is that BMP tests provide data on biogas volume and methane concentration, while EHT does not. However, the EHT as mentioned earlier offers an alternative and rapid method to assess the biodegradability of waste with enough accuracy which positions the method as a good alternative to the widely used EU standardised BM100.

\section{Conclusions}

Overall, this study provided valuable insights into the status quo of waste in landfill sites. We determined that even with current waste diversion policy drivers, there is still a large supply of unspent carbon distributed unequally throughout the landfill sites, which could be converted to biogas via bacterial stimulation for example through leachate recirculation (Woldeyohansa et al., 2014; Sanphotia et al., 2006; Chana et al., 2002; Reinhart et al., 2002 Frank et al., 2016). However it has been proved more problematic in practise (Reinhart et al., 2002) . There was also a direct correlation between landfill age and paper and fines BMP, as well as paper and fines BMP and landfill depth.

The BMP test method used to determine biogas production, while being repeatable and effective, was extremely time and labour intensive. It is therefore impractical for frequent use by landfill operators to attain insightful information about the biogas potential of their waste. Evaluation of the EHT test method, in support of previous studies, determined that there was a high degree of correlation between EHT and BMP test results, which motivates its potential use as an alternative to the BMP test 
method. To date there is little work that has previously been done to describe the relationship between waste characteristics and biogas production in such detail. Such research provides the fundamental basis needed to address and reform waste management practises aimed at deriving value from landfill waste, particularly with regards to waste degradation, and landfill gas production. It also provides valuable information on the limiting chemical and biological mechanisms of biogas production, and thus potential insights to the future of methane recovery from landfill sites.

Acknowledgements: This work was financially supported by the National Research Foundation, South Africa (Ref: SFH20110829000026157) and Viridor Ltd, UK.

\section{References}

Adhikari, B., Dahal, R. and Khanal, N., A. 2014. Review of factors affecting the composition of municipal solid waste landfill leachate. International Journal of Engineering Science and Innovative Technology 3, 273-281.

American Public Health Association (APHA) 2005. Standard Methods for the examination of Water and Wastewater, 21st ed. Washington. American Public Health Association, American Water Works Association, Water Environment Federation, 9-169.

Bogner, J. and Spokas, K., 1993. Landfill $\mathrm{CH}_{4}$ : rates, fates, and role in global carbon cycle. Chemosphere, 26, 369-386.

Brown, K. A., Maunder, D. H. 1994. Exploitation of landfill gas: a UK perspective. Water Science and Technology 30, 143-151. 
Chana, G.Y.S., Chub, L. M., Wong, M.H. 2002. Effects of leachate recirculation on biogas production from landfill co-disposal of municipal solid waste, sewage sludge and marine sediment. Environmental Pollution 118, 393-399.

Contreras, E. M., Bertola, N. C., Giannuzzi, L., Zaritzky, N. E. 2002. A modified method to determine biomass concentration as COD in pure cultures and in activated sludge systems. Water Research South Africa, 28, 463-467.

Defra. 2006. A beginners guide to the landfill allowance trading Scheme (LATS), available at http://archive.defra.gov.uk/environment/waste/documents/latsbeginnersguide.pdf. Accessed on 05/02/2015).

Donovan, S. M., Pan, J., Bateson, T., Gronow, J. R. Voulvoulis, N. 2011. Gas emissions from biodegradable waste in United Kingdom landfills. Waste Management and Research, 29, 69-76.

Emkes H., Coulon F., Wagland S. 2015. A decision support tool for landfill methane generation. Waste Management. 43: 307-318

European Commission, 1999. Council Directive 1999/31/EC of 26 April 1999 on the landfill of waste. Office for Official Publications of the European Communities, Luxembourg.

European Commission, 2008. Directive 2008/98/EC of the European Parliament and of the Council of 19 November 2008 on waste and repealing certain Directives, Office for Official Publications of the European Communities, Luxembourg. European Commission, 2009. Directive 2009/28/EC of the European Parliament and of the Council of 23 April 2009 on the promotion of the use of energy from renewable sources and amending and subsequently repealing certain 
Directives, Office for Official Publications of the European Communities, Luxembourg.

Frank R. R., Davies, S., Wagland, S.T., Villa R., Trois C., Coulon F. 2016.

Evaluating leachate recirculation with cellulase addition to enhance waste biostabilisation and landfill gas production. Waste Management, in press

Garcia, J., Davies, S., Villa, R., Gomes, D.M., Coulon, F., Wagland, S.T. 2016. Compositional analysis of excavated landfill samples and the determination of residual biogas potential of the organic fraction. Waste Management http://dx.doi.org/10.1016/j.wasman.2016.06.003

Godley, A. R., Lewin, K., Graham, A., Barker, H., Smith, R. 2004. Biodegradability determination of municipal waste: an evaluation of methods. Waste 2004 Integrated Waste Management and Pollution Control: Policy and Practice, Research and Solutions, Stratford-upon- Avon, UK.

Johari, A., Ahmed, S. I., Hashim, H., Alkali, H., Ramli, M. 2012. Economic and environmental benefits of landfill gas from municipal solid waste in Malaysia. Renewable and Sustainable Energy Reviews 16, 2907- 2912.

Laner, D., Crest, M., Scharff, H., Morris, J. W. F., Barlaze, M. A. 2012. A review of approaches for the long-term management of municipal solid waste landfills. Waste Management 32, 498-512.

Lee, A.H., Nikraz, H. and Hung, Y.T., 2010. Influence of waste age on landfill leachate quality. International Journal of Environmental Science and Development, 1:347-350. 
Machado, S. L., Carvalho, M. F., Gourc, J., Vilar, O. M., do Nascimento, J. C. F. 2009. Methane generation in tropical landfills: Simplified methods and field results. Waste Management 29, 153-161.

Mor, S., Ravindra, K., Visscher, A. D., Dahiya, R. P., Chandra, A. 2006. Municipal solid waste characterization and its assessment for potential methane generation: A case study. Science of the Total Environment 371, 1-10.

Quaghebeur, M., Laenen, B., Geysen, D., Nielsen, P., Pontikes, Y., van Gerven, T., Spooren, J., 2013. Characterization of landfilled materials: screening of the enhanced landfill mining potential. Journal of Cleaner Production, 55, 72-83.

Rada, E.C., Ragazzi, M., Stefani, P., Schiavon, M., Torretta, V. 2015. Modelling the potential biogas productivity range from a MSW landfill for its sustainable exploitation, Sustainability, 7, 482-495

Reinhart, D. R., McCreanor, P. T., Townsend, T. 2002. The bioreactor landfill: Its status and future. Waste Management and Research 20, 172-186.

Rodriguez, C., Hiligsmann, S., Lardinois, M., Destain, J., Radu, J. P., Charlier, R., Thonart, P. 2001. Cellulose enzymatic availability in solid waste. Proceedings Sardinia 2001, Eighth International Waste Management and Landfill Symposium, CISA, Cagliari.

Sanphotia, N., Towprayoona, S., Chaiprasertc, P., Nopharatanad, A. 2006. The effects of leachate recirculation with supplemental water addition on methane production and waste decomposition in a simulated tropical landfill. Journal of Environmental Management 81, 27-35. 
Shanmugam, P., Horan, N. J. 2008. Simple and rapid methods to evaluate methane potential and biomass yield for a range of mixed solid wastes. Bioresource Technology 100, 471-474.

Staley, B.F., Francis, L. and Barlaz, M.A., 2011. Effect of spatial differences in microbial activity, $\mathrm{pH}$, and substrate levels on methanogenesis initiation in refuse. Applied and Environmental Microbiology, 77, 2381-2391.

Wagland, S.T. , 2008. Development and evaluation of rapid enzymatic hydrolysis test method to assess the biodegradability oforganic waste. $\mathrm{PhD}$ thesis, Cranfield University, Cranfield.

Wagland, S. T., Tyrrel, S. F., Godley, A. R., Smith, R., Blakey, N. 2007. Development and application of an enzymatic hydrolysis test to assess the biodegradability of organic waste material. Proceedings Sardinia 2007, Eleventh International Waste Management and Landfill. Symposium, CISA, Cagliari

Wagland, S.T., Godley, A.R., Frederickson, J., Tyrrel, S.F., Smith, R. 2008. Comparison of a novel enzymatic biodegradability test method with microbial degradation methods. Communications in Waste and Resource Management 9, $80-86$.

Wagland, S. T., Tyrell, S. F., Godley, A. R., Smith, R. 2009. Test methods to aid in the evaluation of the diversion of biodegradable municipal waste (BMW) from landfill. Waste Management 23, 1218-1226.

Wagland, S.T., Godley, A.R., Tyrell, S. F. 2011. Investigation of the application of an enzyme-based biodegradability test method to a municipal solid waste biodrying process. Waste Management 31, 1467-1471. 
Walker, M., Banks, C., Heaven, S., Frederickson, J. 2010. Residual biogas potential test for digestates, available at http://www.wrap.org.uk/sites/files/wrap/Residual\%20Biogas\%20Potential.pdf (Accessed on 5th January 2015).

Woldeyohansa, A. M., Workub, T., Kloosc, H., Mulat, W. 2014. Treatment of leachate by recirculating through dumped solid waste in a sanitary landfill in Addis Ababa, Ethiopia. Ecological Engineering 73, 253-259. 


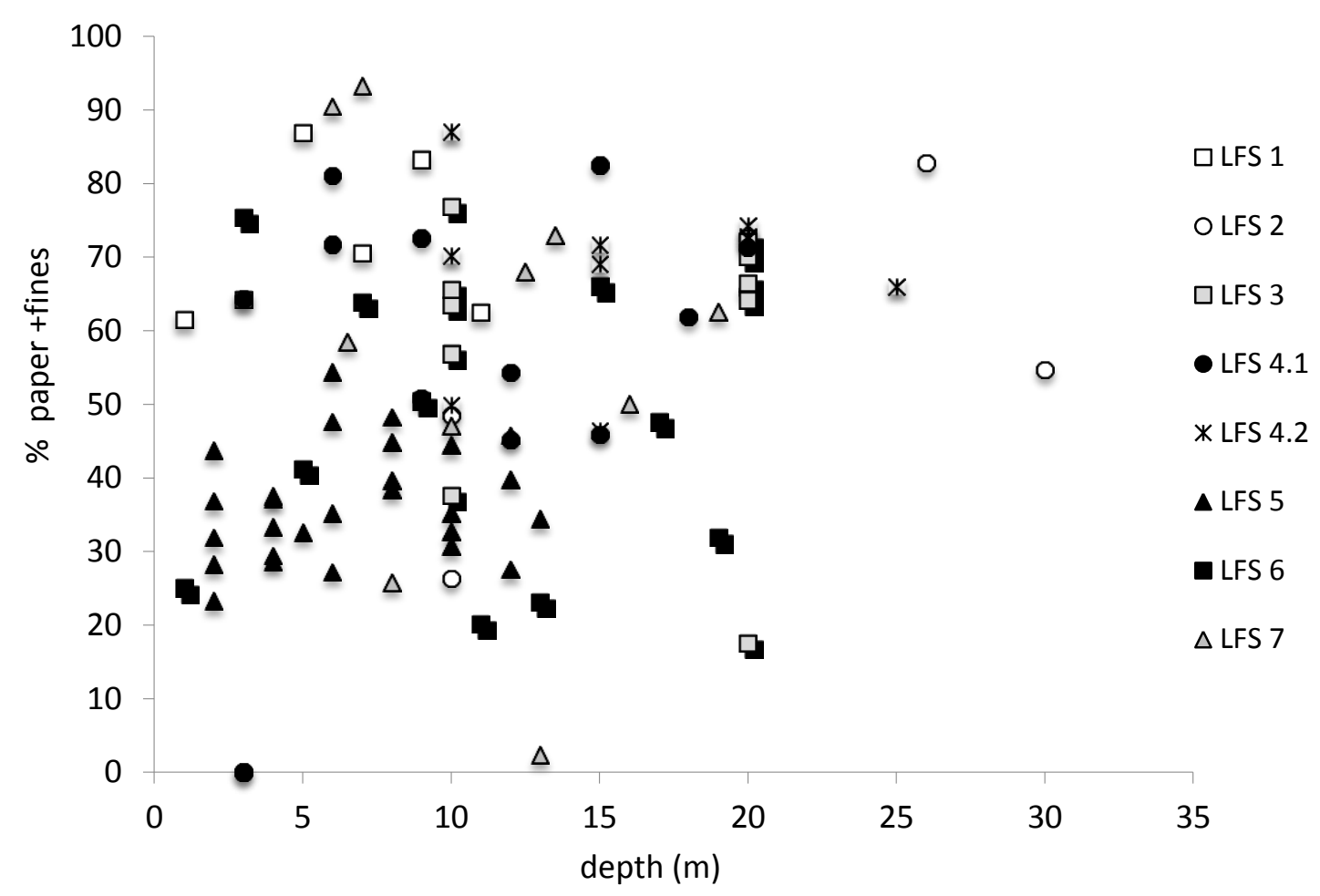

Figure 1: Spatial distribution of the paper and fines from seven UK landfill sites 

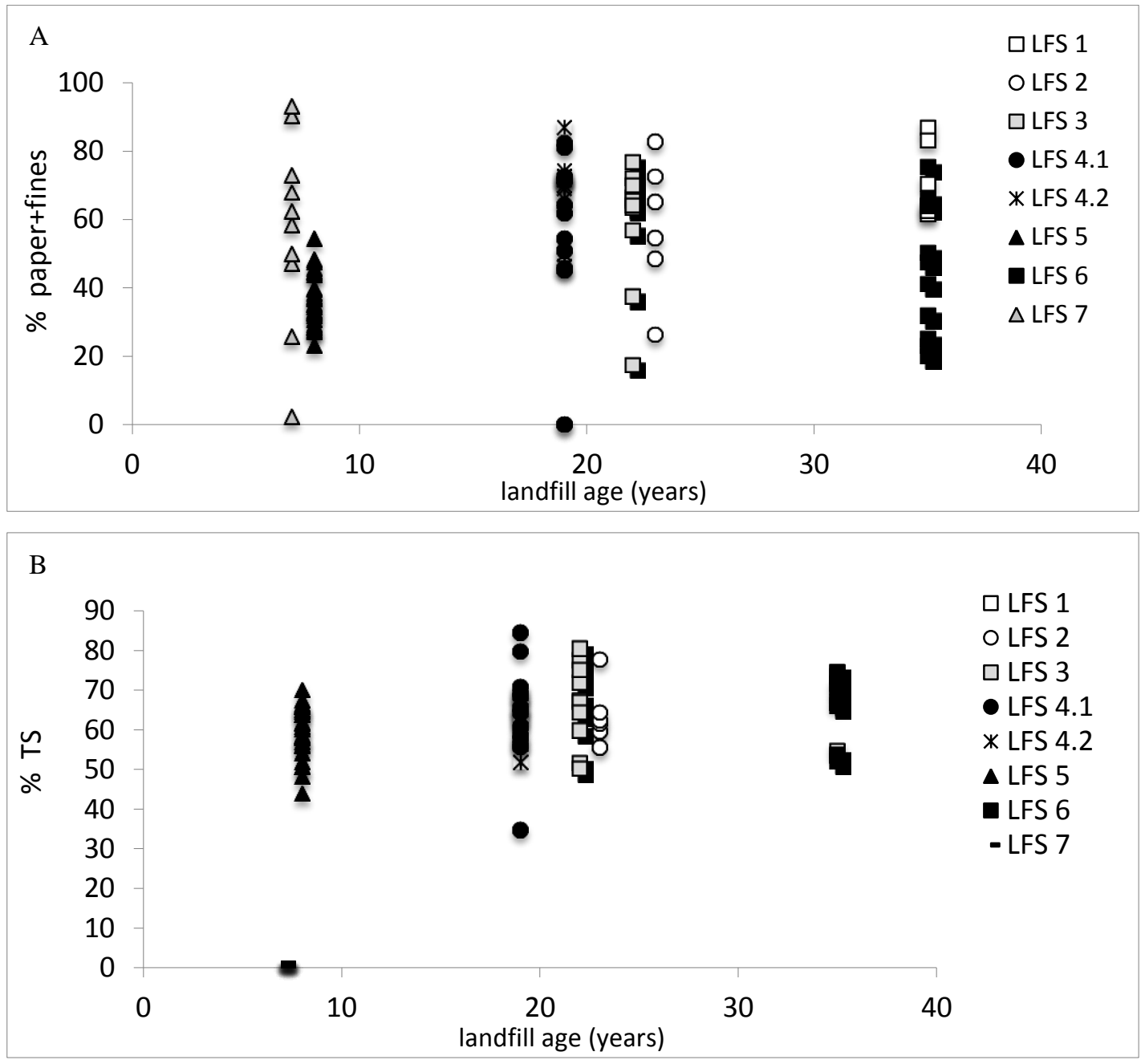

$\mathrm{C}$

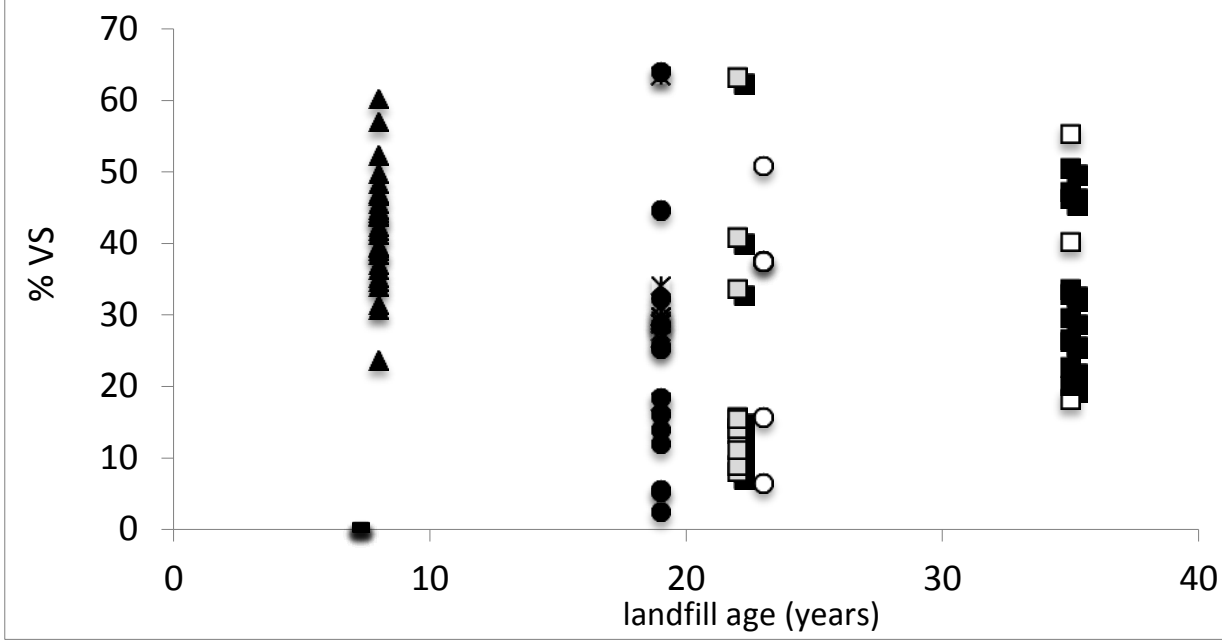

Figure 2: Percentage range distribution of paper + fines (A), \%TS (B) and \%VS (C) according to landfill age 


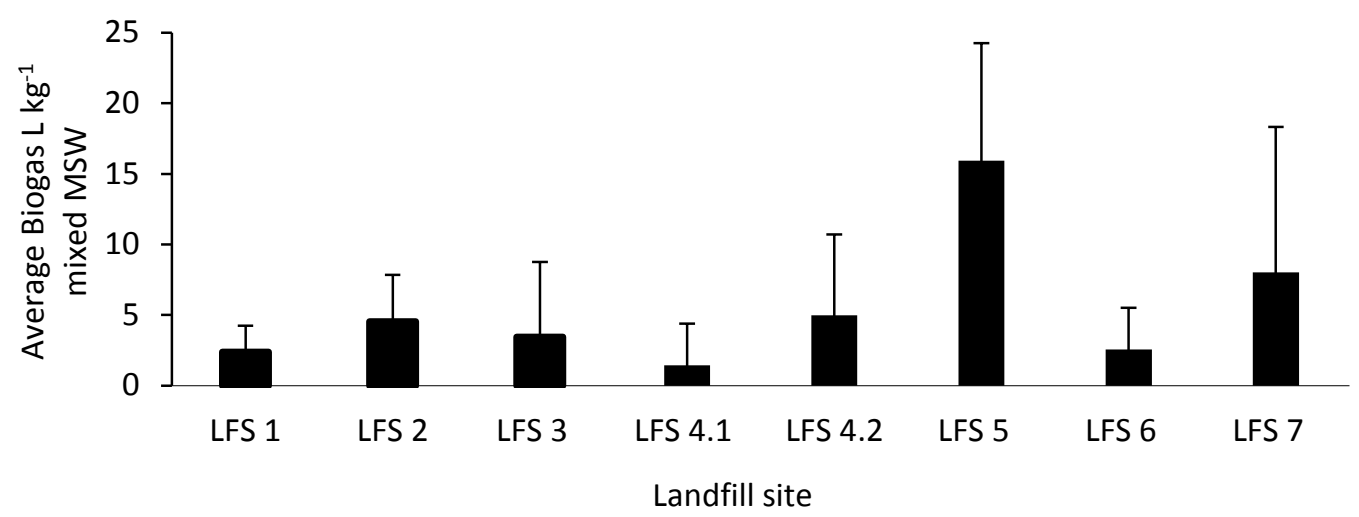

Figure 3: Average biogas production from BMP tests across seven UK landfill sites (including standard deviation)

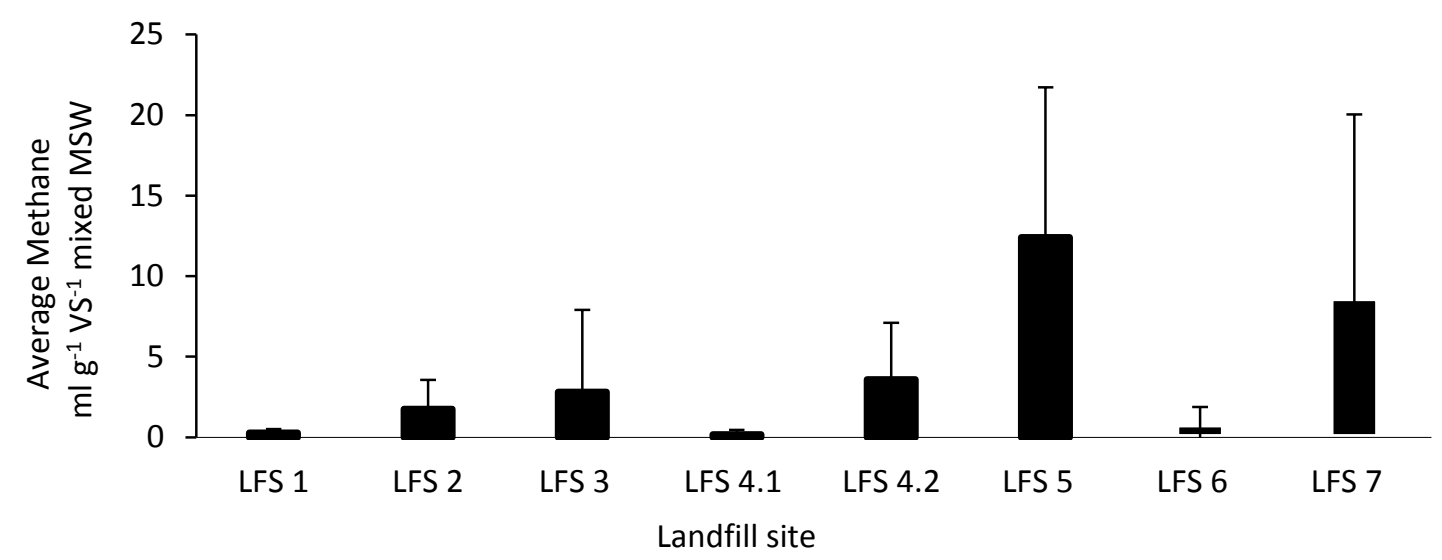

Figure 4: Average methane production from BMP tests across the seven landfill sites (including standard deviation)

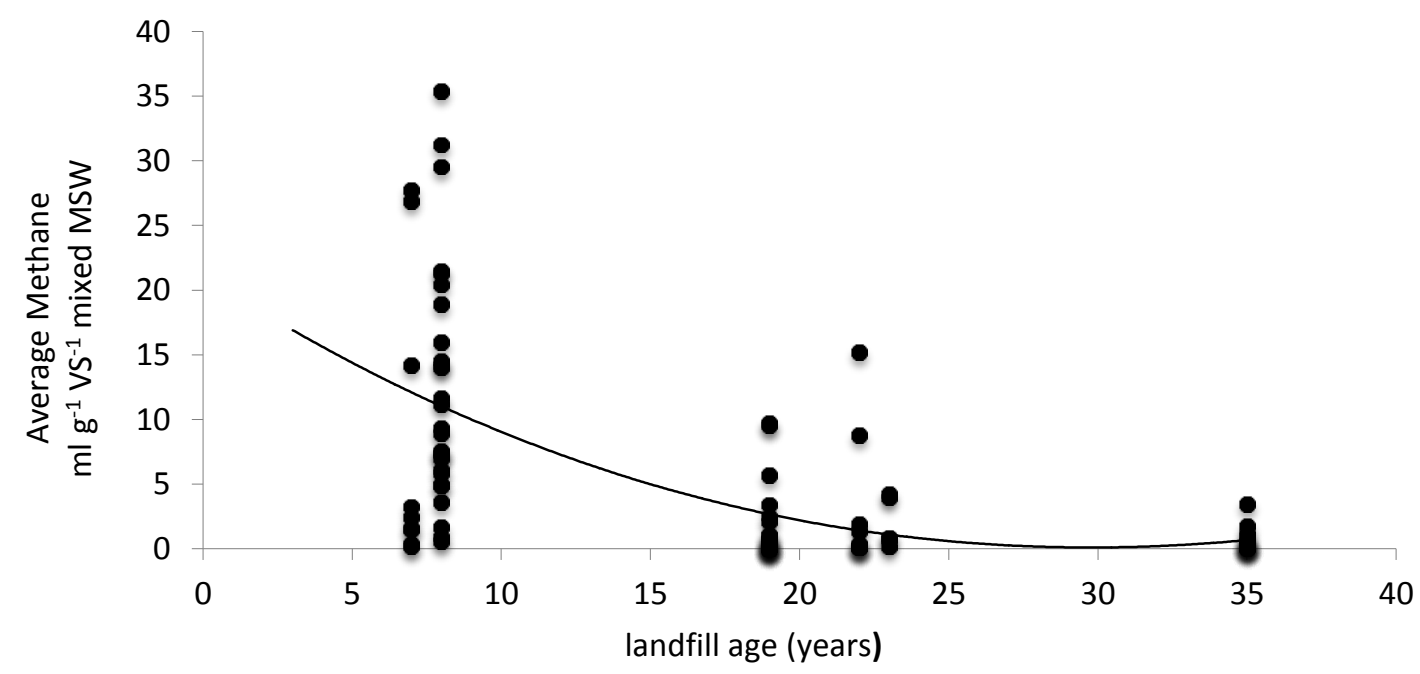

Figure 5: Methane yield according to landfill age 


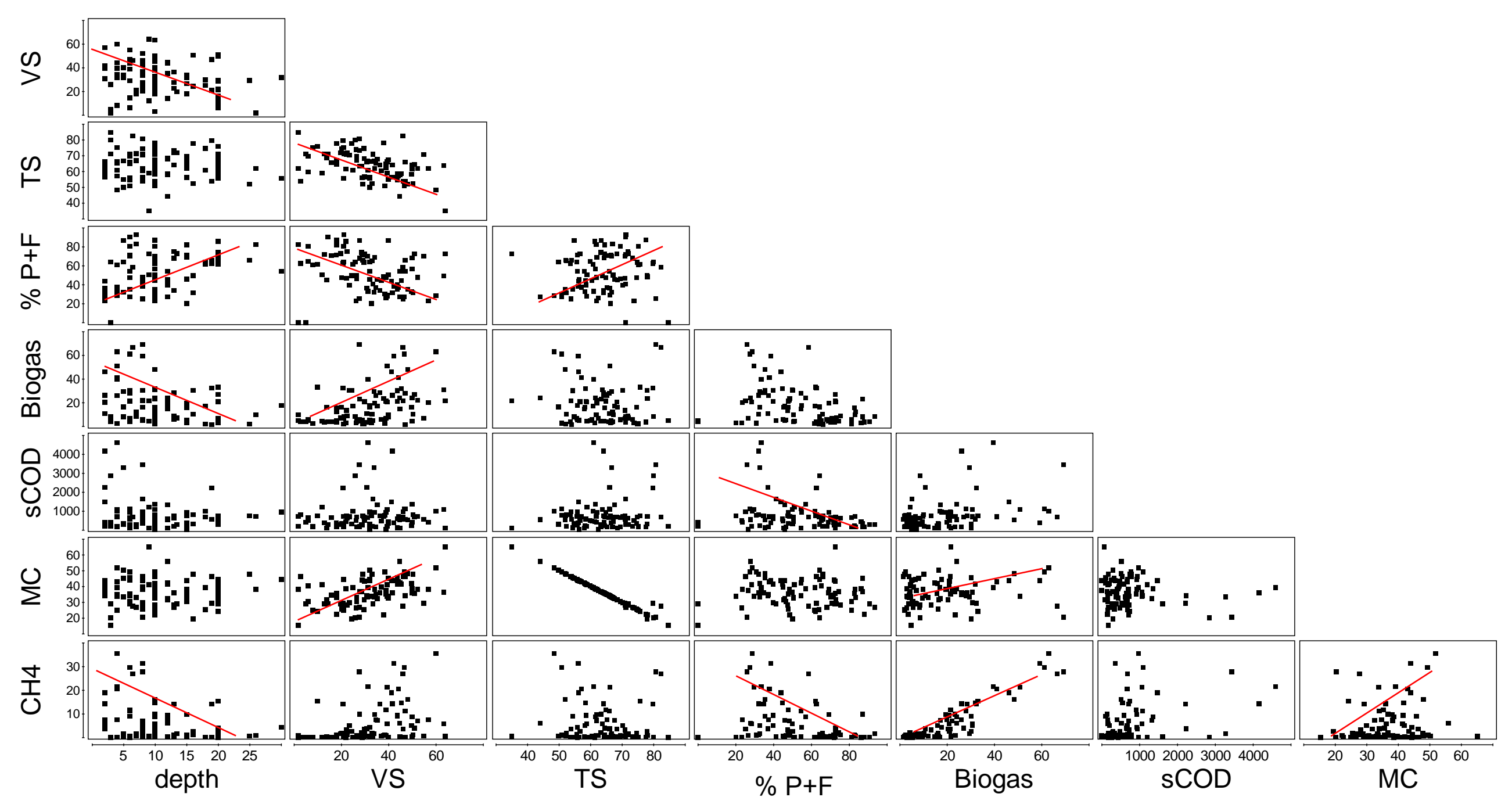

1 Figure 6: Draftsman's plot presenting the relationships between waste depth (m), VS (\%), TS (\%), paper and fines (P+F) composition (\%), sCOD (mg

$\left.3 \mathrm{~L}^{-1}\right)$, biogas production $\left(\mathrm{L} \mathrm{kg}^{-1}\right.$ waste) and $\mathrm{CH}_{4}$ production $\left(\mathrm{ml} \mathrm{g}^{-1} \mathrm{VS}^{-1}\right)$. 


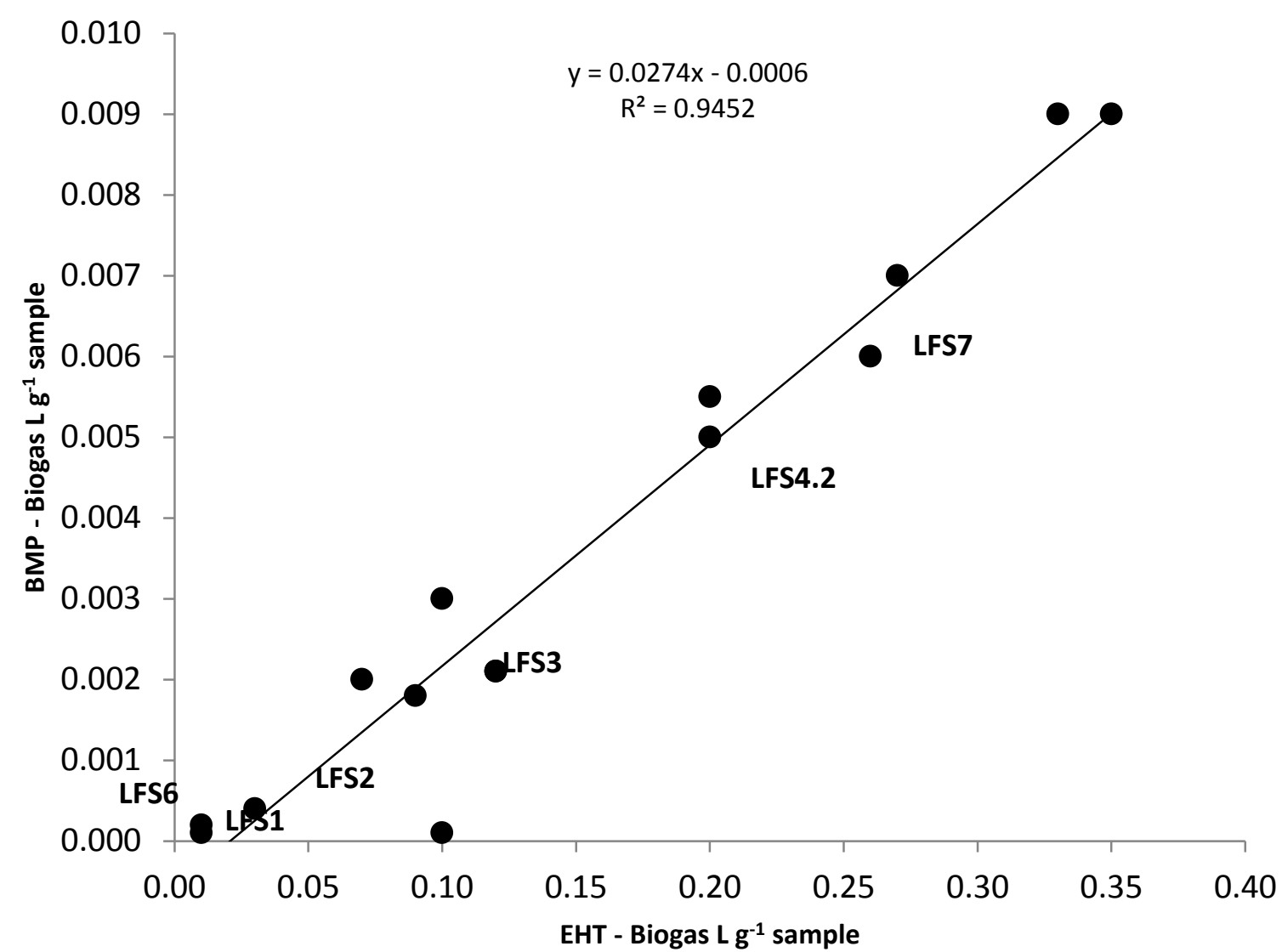

5

Figure 7: Correlation between the BMP and EHT values across the seven landfill sites. 7 
Table 1: Background information on the tested landfill sites 1-7

\begin{tabular}{|l|c|c|c|c|}
\hline Landfill site & $\begin{array}{c}\text { Age of landfill site (as of } \\
\text { 2015) (years) }\end{array}$ & $\begin{array}{c}\text { Status of landfill (as of } \\
\text { 2015) }\end{array}$ & Capacity of site (Mt) & Tonnage received per year (kt year ${ }^{-1}$ ) \\
\hline LFS 1 & 35 & Closed & 5.8 & $200-300$ \\
\hline LFS 2 & 23 & Open & 6.6 & 300 \\
\hline LFS 3 & 22 & Open & 4.2 & $200-250$ \\
\hline LFS 4 & 19 & Closed & 5.0 & $200-250$ \\
\hline LFS 5 & 8 & Open & 0.9 & 100 \\
\hline LFS 6 & 35 & Open & 1.4 & 50 \\
\hline LFS 7 & 7 & Closed & 1.1 & $100-150$ \\
\hline
\end{tabular}

9

10 Table 2: Characteristics of the enzymatic mixtures used during the EHT test

\begin{tabular}{|l|l|r|r|r|}
\hline \multicolumn{1}{|c|}{$\begin{array}{c}\text { Enzymatic } \\
\text { mixture }\end{array}$} & \multicolumn{1}{|c|}{$\begin{array}{c}\text { Enzyme } \\
\text { supplier }\end{array}$} & Weight per sample (mg) & Concentration (U/mg) & $\begin{array}{c}\text { Units } \\
\text { (U/mg solid) }\end{array}$ \\
\hline Cellulase & Sinobios & 2.67 & 300 & 800 \\
\hline Hemicellulase & Sigma & 133 & 1.5 & \\
\hline
\end{tabular}

11

12 
13 Table 3: Physicochemical characteristics of the waste materials collected across the 7 LFS at the different depths

\begin{tabular}{|c|c|c|c|c|c|c|c|c|c|c|c|c|c|c|c|}
\hline \multirow{2}{*}{ Site } & \multicolumn{3}{|c|}{ TS (\%) } & \multicolumn{3}{|c|}{ VS (\%) } & \multicolumn{3}{|c|}{$\mathrm{sCOD}\left(\mathrm{mg} \cdot \mathrm{L}^{-1}\right)$} & \multicolumn{3}{|c|}{$\mathrm{pH}$} & \multicolumn{3}{|c|}{ Moisture content (\%) } \\
\hline & $0-9 m$ & $10-19 m$ & $20+m$ & $0-9 m$ & $10-19 m$ & $20+m$ & $0-9 m$ & $10-19 m$ & $20+m$ & $0-9 m$ & $10-19 m$ & $20+m$ & $0-9 m$ & $10-19 m$ & $20+m$ \\
\hline LFS 1 & $64 \pm 10$ & $55 \pm 0$ & - & $32 \pm 17$ & $14 \pm 0$ & - & $294 \pm 154$ & $792 \pm 0$ & - & $7.6 \pm 0$ & $8.3 \pm 0$ & - & 37 & 46 & - \\
\hline LFS 2 & - & $64 \pm 12$ & $56 \pm 6$ & - & $30 \pm 11$ & $32 \pm 13$ & - & $706 \pm 0$ & $688 \pm 186$ & - & $7.6 \pm 1$ & $8.3 \pm 1$ & - & 30 & 40 \\
\hline LFS 3 & - & $64 \pm 10$ & $68 \pm 7$ & - & $31 \pm 14$ & $24 \pm 18$ & - & $526 \pm 113$ & $226 \pm 645$ & - & $7.6 \pm 0$ & $7.8 \pm 0$ & - & 35 & 32 \\
\hline LFS 4.1 & $66 \pm 11$ & $65 \pm 7$ & $65 \pm 0$ & $18 \pm 16$ & $30 \pm 17$ & $12 \pm 0$ & $640 \pm 983$ & $689 \pm 426$ & $652 \pm 42$ & $7.1 \pm 1$ & $7.6 \pm 2$ & $5.7 \pm 0$ & 37 & 39 & 37 \\
\hline LFS 4.2 & - & $65 \pm 3$ & $60 \pm 7$ & - & $33 \pm 16$ & $29 \pm 1$ & - & $545 \pm 394$ & $543 \pm 211$ & - & $7.8 \pm 0$ & $7.3 \pm 0$ & - & 36 & 42 \\
\hline LFS 5 & $60 \pm 6$ & $56 \pm 8$ & - & $41 \pm 9$ & $42 \pm 0$ & - & $1290 \pm 1328$ & $647 \pm 321$ & - & $7.0 \pm 0$ & $7.3 \pm 0$ & - & 37 & 35 & - \\
\hline LFS 6 & $66 \pm 11$ & $65 \pm 9$ & - & $33 \pm 13$ & $33 \pm 11$ & - & $961 \pm 638$ & $642 \pm 105$ & - & $7.3 \pm 1$ & $8.0 \pm 1$ & - & 33 & 34 & - \\
\hline LFS 7 & $76 \pm 5$ & $73 \pm 1$ & - & $25 \pm 10$ & $24 \pm 6$ & - & $1126 \pm 1227$ & $219 \pm 65$ & - & $7.6 \pm 1$ & $7.8 \pm 0$ & - & 26 & 26 & - \\
\hline
\end{tabular}

14

15 TS, VS, sCOD, $\mathrm{pH}$ and MC results are the average of all samples attained \pm standard deviation (SD). Each sample was tested in triplicate except for 16 sCOD which was tested in duplicate. sCOD standard deviation is high due to waste heterogeneity across depths.

17

18

19

20

21 